\title{
An assessment of mangrove management during the colonial and post-colonial periods
}

\author{
V. Selvam
}

\begin{abstract}
Mangroves of the east coast of India were brought under intensive management by the colonial authorities during the late 19th century. They were treated as forests rather than as wetlands, and hence management procedures developed for the terrestrial forests were applied to mangroves. Apart from this, the British foresters had limited mangrove tree mensuration data. This inadequacy in data led to the application of inappropriate silviculture methods such as clear felling to harvest mangrove wood products. This method triggered a chain reaction, that changed the biophysical condition of the clear-felled areas, which in turn prevented the regeneration of mangrove species. The same silvicultural system was followed during the post-colonial period leading to extensive degradation of mangroves.
\end{abstract}

Keywords: Biophysical changes, clear felling, forestry management, large-scale degradation, mangroves.

MANGROVES, a dominant feature of tropical and subtropical coasts, are rich in directly harvestable wood and nonwood products. The mangrove wood products include timber, scaffolds, poles and beams for house construction, dock and bridge pilings, boat-building, while the major non-wood products are tannin, honey and wax ${ }^{1}$. Economic importance of mangroves that stems from these products was documented by European botanical explorers and foresters of the colonial period starting from the early 19th century. In 1804 itself, a method of extracting tannin from the mangrove bark collected from India was developed, for which a chemist received a gold medal from a Society in London ${ }^{2}$. The quality of the wood of a few mangrove species was briefly discussed by Belfour $^{3}$ in 1870 whereas in 1890 , Watt provided a detailed account of the characters, quality and uses of wood of major mangrove species ${ }^{4}$. He described that the wood of Heritiera fomes was the toughest that had been tested in India at that time with a breaking weight of $513 \mathrm{~kg}$, whereas the same that of Burmese teak wood was only $394 \mathrm{~kg}$. It was also mentioned that when the Heritiera wood was burnt, it produced the best charcoal for the manufacture of gun powder. It is well known that charcoal made from many mangrove trees has high heat combustion and burns longer with low spark, and less smoke and because of these qualities mangroves in many South Asian countries are still exploited for charcoal production $^{1}$. Apart from the directly harvestable products for commercial purposes, many of the mangrove trees also have favourable silvicultural characteristics such as high

V. Selvam is in the M.S. Swaminathan Research Foundation, 3rd Cross Street, Taramani Institutional Area, Taramani, Chennai 600 113, India. e-mail:vselvam45@hotmail.com growth rate, the tendency to form monospecies, and evenaged stand and capacity to recover rapidly from natural disturbances such as cyclones and human-induced disturbances like intensive logging ${ }^{1}$. In India, mangroves were brought under intensive scientific forest management during the colonial and early post-colonial periods with an aim to exploit mainly wood products that can be marketed immediately. This article analyses these management practices and how they impacted mangrove wetlands, which still has bearing on the management of Indian mangroves.

\section{Scientific forest conservancy during the colonial period}

The first large-scale deforestation of Indian forests by the British started in the late 18th century and continued till the early 19th century mainly for expansion of agriculture, exploitation of timber for the Royal Navy and valuable wood such as sandalwood for revenue generation ${ }^{5}$. The second wave of threat to Indian forests came in the middle of the 19th century, when the British decided to establish an extensive network of railways in India to improve commerce and help in the movement of troops. The first commercial passenger railway line was started in 1853 for a length of about $32 \mathrm{~km}$, which within about 20 years increased exponentially to about $7600 \mathrm{~km}$. One kilometre of rail track required 700-750 sleepers and the volume of each sleeper was 3.5 cubic feet. Large areas of forests throughout India were denuded to supply these sleepers as well as firewood for locomotives ${ }^{6,7}$. According to Stebbing $^{8}$, the harvest of wood for railways was done without any supervision and as a result, several trees were 
felled without assessing the possibility of extracting logs suitable for railways and these felled trees were left in the forest itself to decay. Though the British colonial government mainly attached materialistic value to the forests, overexploitation of timber and reckless destruction of forests caused great concern among the administrators, with reference to future supply of timber. In 1850, the British Association for the Advancement of Science appointed a Committee to examine the effects of the destruction of forests and suggest measures to reduce the impact. The committee headed by Hugh Cleghorn (who was later recognized as the Founder of Forest Conservancy in India by the British government in 1861) thoroughly analysed various reports and evidence provided on the destruction of forests in various provinces of British India. The committee, recommend that (i) more forest should be brought under the control of the government, (ii) seedlings should be planted in the place of mature trees when removed, (iii) cutting of trees must be avoided before they are fully grown and (iv) indiscriminate clearing of forests should be avoided in the localities around springs from where rivers originate ${ }^{9}$. Subsequently, the Imperial Royal Forest Department was established in India in 1864, which signalled the introduction of scientific forestry in the country.

In order to obtain a regular supply of timber and other forest produce in greater quantity perpetually, it was envisaged by the colonial foresters that the forests should be managed scientifically. According to Presler ${ }^{10}$, the major principles of scientific forestry during the colonial period were: (i) state competence (the state is more competent in terms of technical know-how and capacity to invest for a long-term in forest management), (ii) state ownership, (iii) forest economy, and (iv) rights and privileges of the local population. As a first step to achieve scientific forestry, the Government Forests Act was passed in 1865, which authorized authorities to declare any land covered with trees, brushwood and jungle (including mangroves) as a government forest by notification in the Official Gazette. This Act was passed primarily to take over control of timber-rich forests to supply wood to the railways and other public works ${ }^{11}$. Many British forest administrators considered this Act to be deficient in regulating the rights of the local people and wanted to have more stringent rules in the management of government forests. In 1878, the Government Forests Act 1865 was repealed and the Indian Forest Act 1878 was passed. According to this Act, there would be only two types of forests in India: (1) government forests and (2) forests owned by private parties. The government forests were further divided into three types on the basis of access and control over the resources: (i) reserved forests, (ii) village forests and (iii) protected forests. Reserved forests were declared as the absolute property of the government, and people could claim no rights on timber or any other wood and non-wood produce. Forests that had the potential to be declared as reserved forests were declared as protected forests and customary rights of the individuals and communities on forest produce were recognized, however, to ascertain and settle the same, elaborate processes were stipulated. The village forests remained inoperative for various reasons ${ }^{5}$.

In the scientific forest conservancy introduced during the period, forest economy remained as the central concept. The forests were considered as a kind of capital producing a certain amount of interest in wood by its annual growth, just as a sum of money which is lent out produces interest, and the foresters were advised to strictly follow the principle 'take the interest and not trench on the capital ${ }^{12,13}$. According to Ribbentrop ${ }^{12}$, the sustained maximum yield of forest produce could be achieved through the organized forests. The organized forests had to be built up of an unbroken series of trees of all ages, from the seedlings to the mature trees. Thus, forestry during the colonial period, apart from bringing forests under the control of the government, focused on (i) assessing stock of the forests by measuring the annual growth rate of principal trees (those selected for exploitation) and measuring wood volume, (ii) enumerating the value of harvestable wood, (iii) determining rotation length (exploitable age), (iv) identifying methods of exploitation, and (v) identifying methods of regeneration to replenish the stock. Once all the required data were obtained (which were many and complex), a forest working plan containing details of stock available, age classes, volume (cubic feet), amount that can be exploited annually or out-turn, method of harvesting, expected cost-benefit, etc. was prepared by the designated forester officers. Preparation of the working plan was considered as the summit of forestry science ${ }^{5}$.

\section{Mangrove management during the colonial period}

British administrators for long considered mangroves as a breeding place of malaria, home to wild beasts and hiding place for dacoits and pirates, and hence better to be cleared $^{13}$. Cleghorn ${ }^{14}$ mentioned that the mangrove belts of the Godavari and Krishna delta could be cleared to increase the area of cultivation and easy movement of troops. Apart from these, the British government considered only a few species of mangroves such as Heritiera which had value as timber. Less or no value attached to the mangroves by the British administrators initially led to their large-scale clearing for agriculture.

The clearing of Sundarbans mangroves was the first to start as early as 1783 , when a proposal was made to the Governor-General of British India for clearing the same mangroves with the objective of bringing the Sundarbans 
'waste' into cultivation. As shown in Table 1, in 1873 , the Commissioner of Sundarbans showed how much area of mangroves had already been cleared and how much was planned to be cleared in the future ${ }^{15}$. This indicates that the primary aim of the British Bengal administration was to reclaim the mangroves for agriculture development.

During the colonial period, almost all the mangroves of Odisha were found within the feudal state of Kanika. According to Hossain ${ }^{16}$, about 41,958 ha of land $(36.82 \%$ of the total area of Kanika) was under mangroves which were mainly exploited for firewood and posts for cottagebuilding. Like Sundarbans, the mangroves of Odisha were also cleared for agriculture by farmers as well as officials of the Kanika Raj. Outsiders were also allowed to clear mangroves for rice cultivation. For example, in 1879, the Raja of Kanika granted an European about 900 ha of mangroves for conversion into agriculture.

\section{Constitution of mangroves as reserved forests}

When the mangroves of Sundarbans were rapidly converted into agriculture land, William Schlich, who was the Head of the Forest Department in Bengal in 1876, took the first step to bring them under scientific management. He wrote an article in the Indian Forester in which he explained the value of Sundarbans mangroves and the silviculture potential of many mangrove species, and urged the government to stop converting mangroves into agriculture. He also suggested bringing the entire Sundarbans under forest management ${ }^{17}$. Accordingly, Sundarbans mangrove forests were divided into four blocks, namely Bagerhat, Khulna, Satkhira and 24-Parganas; the first three were declared as reserved forests in 1879, and the 24-Parganas block was declared as a protected forest in 1878 according to the Indian Forest Act, 1878.

Similarly, mangroves in the Godavari and Krishna districts of the Northern Circars of the Madras Presidency were notified as reserved forests between 1886 and 1890 (ref. 18). According to Hemingway ${ }^{19}$, the mangroves of Godavari extended for a length of 35 miles $(56 \mathrm{~km})$ from Coringa in the north and Narasupur in the south with an average width of 5 miles $(8 \mathrm{~km})$, which is approximately equal to 44,800 ha. About one-third of this was owned by the then Zamindars, and in this portion the mangroves

Table 1. Total area of Sundarbans mangroves in 1873, area already cleared and area earmarked for future clearing

\begin{tabular}{lr}
\hline Category & Area (ha) \\
\hline Mangroves already cleared for cultivation & 279,226 \\
Mangrove set apart for further clearing for cultivation & 155,822 \\
Mangroves not leased for clearing & $1,027,445$ \\
Area occupied by navigable rivers, canals and creeks & 488,027 \\
Total area & $19,950,520$ \\
\hline
\end{tabular}

had already been overexploited and only a scrub jungle was present. The remaining mangroves, owned by the government, were used mainly as a source of firewood. The Pichavaram mangroves in modern-day Tamil Nadu were declared as a reserved forest in 1893. Though the flora of mangroves of the west coast of India was explored and documented during the early period of the colonial rule, none of the mangroves was brought under government control. This may be due to small size of the mangroves and poor stocking as in the case of Gujarat mangroves. Most of the mangroves of the west coast remained under the control of the Revenue Department, both during the colonial and immediate post-colonial period $^{20}$.

\section{Exploitation of mangroves}

The main aim of the management of Indian mangroves during the colonial period was to produce firewood for the railways, iron smelting, sugarcane and cotton mills, brick kiln and local consumption, particularly in the nearby cities and towns ${ }^{21}$. In the specific case of Sundarbans mangroves, it was to produce timber, firewood and thatching materials to the whole of Bengal and Calcutta. In all these mangroves, clear felling was the system employed to exploit the mangrove forests ${ }^{22-24}$. According to this system, an entire forest division or a part of it is declared as a working circle which is divided into many felling series and each felling series is further divided into annual coupes. The size of the annual coupes is decided by the rotational age of the forest for exploitation. The age of the forest (trees of major stock of the forest or targeted species) at which the maximum sustainable yield can be achieved is known as the rotational age. Thus, for example, if the area of a felling series of a mangrove forest is 500 ha and its rotational period is 20 years, then the area of one annual coupe will be 25 ha and the number of annual coupe will be 20 . In the first year, trees in the first coupe will be felled, and in the felled areas new growth will be achieved either through natural or artificial regeneration or by both. In the second year, a similar process will be followed in the second coupe, and this will continue until felling is completed in the 20th year in the 20th coupe. In the 21 st year, the first coupe will be ready with a stock of trees of rotational age 20 years, which will enter into the second felling cycle. Theoretically, it looks like a simple exercise, but in practice it is complex and requires enormous as well as reliable mathematical and statistical data.

In the mangroves of Godavari, Krishna and Cauvery delta, which the British foresters considered stocked with poor quality wood, the following methods of the clearfelling system were employed: (a) clear felling but retaining trees less than 3 in grith, (b) simple coppice system (natural regeneration through shoots that originate from 
GENERAL ARTICLE

Table 2. Area of mangroves clear-felled and yield obtained in the mangroves of Krishna delta during 1893-1895 (ref. 25)

\begin{tabular}{lccccccr}
\hline & \multicolumn{2}{c}{ Coupe I felled in 1893-94 } & & \multicolumn{2}{c}{ Coupe II felled in 1894-95 } \\
\cline { 2 - 3 } & Area (acres) & Yield (tonnes) & Revenue (Rs) & Area (acres) & Yield (tonnes) & Revenue (Rs) \\
\hline Masulipatanam Working Circle & 1160 & - & - & 1062 & 125 & 312 \\
Avanigadda & 2280 & 2614 & 6545 & & 1690 & 1114 & 2784 \\
Repalle & 1690 & 1821 & 4560 & & 806 & 1981 & 4954 \\
Total & 5130 & 4435 & 11,105 & & 3558 & 3220 & 8050 \\
\hline
\end{tabular}

Table 3. Amount of wood exploited from the Sundarbans mangroves during $1928-29$ (ref. 22, 1 mound $=37.32 \mathrm{~kg}$ )

\begin{tabular}{lcc}
\hline Moundage of boat & $\begin{array}{c}\text { Number of } \\
\text { boat loads }\end{array}$ & $\begin{array}{c}\text { Mounds of forest produce } \\
\text { exported out of Sundarbans }\end{array}$ \\
\hline 100 mounds and less & 59,038 & $2,889,275$ \\
$125-200$ & 12,677 & $2,071,900$ \\
$225-300$ & 4,381 & $1,165,400$ \\
$325-400$ & 1,968 & 711,975 \\
$425-500$ & 1,912 & 882,550 \\
$525-1000$ & 3,761 & $2,871,525$ \\
$1100-2000$ & 1,109 & $1,536,300$ \\
$2100-5000$ & 487 & $1,397,100$ \\
Over 5000 & 6 & 33,500 \\
Total & 85,339 & $13,359,525$ \\
\hline
\end{tabular}

stumps or stools), and (c) coppice with standards (leaving a few mature trees in the felled area for regeneration from seeds along with coppice shoots). The rotational age ranged from 5, 15, 20 to 25 years $^{23,24}$. By following these methods, large areas of mangroves were clear-felled in the Godavari, Krishna and Cauvery delta every year; Table 2 shows an example ${ }^{25}$. In the case of Sundarbans, where good-quality timber was available in plenty, selection-cum-improvement felling (selective felling of trees of exploitable age at frequent intervals) was employed and wherever the quality of wood was considered to be poor, clear-felling system was adopted to exploit large quantities of mangrove timber and firewood. Table 3 shows that about 5 lakh tonnes of wood was exploited from the Sundarbans mangroves in 1928-29 alone.

\section{Mangrove management during the post-colonial period}

Little changes were made in the policy and procedures of forest and mangrove management in the post-colonial period, particularly regarding state ownership, denial of access to the forest resources by the local people, and forest economics remained the central theme of forest management. The role of forests contributing to the national economy was given more importance rather than giving priority to the needs of the local people ${ }^{26}$. As a result, the same silvicultural system, clear felling, was followed in large scale exploitation of mangrove wood during the post-colonial period. As an example, Table 4 shows the area of mangroves clear-felled, yield realized and revenue earned in the Tamarankottai Reserved Forest, Muthupet region, Tamil $\mathrm{Nadu}^{27}$. In some locations, a considerable area of mangroves was converted for other purposes. For example, in 1978, in the Maravakkadu Reserved Forest, Muthupet, Tamil Nadu, about 800 ha of degraded mangrove was converted into salt pans. Felling of trees by the Forest Department and dereservation of reserved forests were stopped only after the promulgation of the Indian Forest (Conservation Act), 1980.

\section{Impact of scientific mangrove management}

Mangroves fulfil all the three basic conditions of a wetland: the land supports plants that are adopted to wet soil condition, the basement is predominately undrained hydric soil, and the soil is saturated or inundated with water at least during the growing period of the plants and hence, mangroves should be managed as a wetland. However, both during the colonial and post-colonial period mangroves were considered as a forest and as a result, the systems and procedures developed to exploit wood of terrestrial forests were also applied to mangroves. Forest mensuration is a major requirement for planning exploitation of wood resources. However, foresters during the colonial period faced hardships in preparing working plans for mangroves due to availability of limited data, which in turn was mainly due to non-availability of skilled personnel, marshy nature of the mangroves, remote location, deformed nature of many of the mangrove trees, and cost involved in the surveys. This inadequacy in data led to selection of inappropriate management practices such as the clear felling of mangrove trees on a large scale, which triggered a chain reaction (Figure 1). Exposure of mangrove soil due to clear felling caused evaporation of soil water, which in turn caused subsidence of sediments leading to changes in the topography of the clear felled areas into shallow troughs. Subsidence of sediments is a common feature in wetland soils which are exposed to prolonged solar radiation ${ }^{28,29}$. Stephens and Speir $^{30}$ observed surface subsidence of mangrove sediments in the Florida Everglades, USA, in areas where peat soils, originated from mangroves, were cleared for agriculture development. Allen ${ }^{28}$ explained that evaporation of soil water in peaty areas results in subsidence for two reasons. Peat soil is commonly underlined by and frequently interbedded with fine sediments 


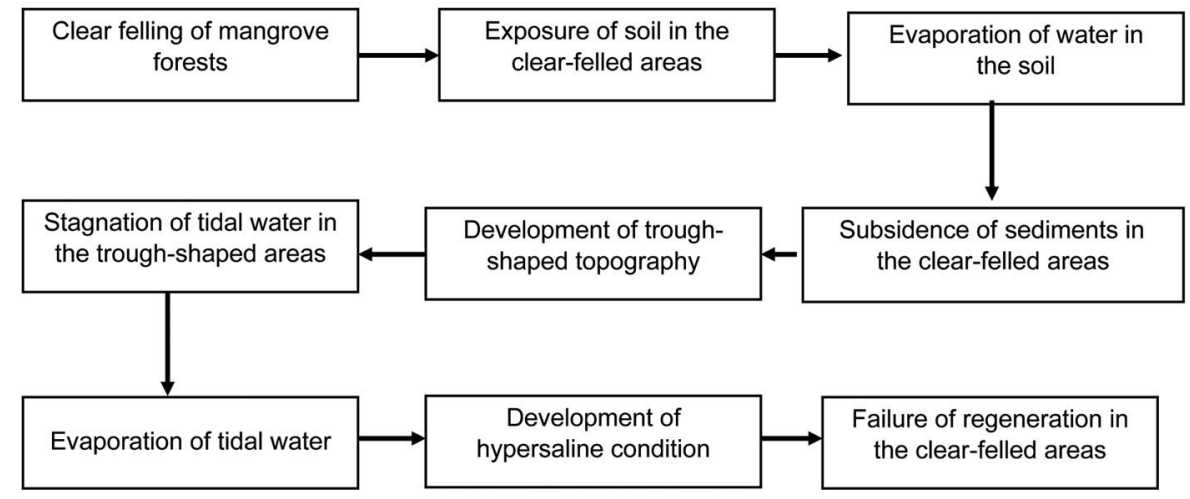

Figure 1. Chain reaction triggered by clear felling leading to failure of regeneration of mangroves in the clear-felled areas.

Table 4. Area of mangroves exploited by clear felling in the Taramankottai Reserved Forests, Muthupet region, Tamil $\mathrm{Nadu}^{27}$

\begin{tabular}{lcccc}
\hline & \multicolumn{4}{c}{ Tamarankottai Reserved Forest } \\
\cline { 2 - 5 } Year & Coupe number & Area (ha) & Yield (tonne) & Amount (Rs) \\
\hline $1960-61$ & I & 53.82 & 365.00 & $7,151.00$ \\
$1962-63$ & II & 40.47 & 327.50 & $9,000.00$ \\
$1963-64$ & III & 40.47 & 260.50 & $9,050.00$ \\
$1966-67$ & VII & 40.47 & 336.67 & $5,500.00$ \\
$1969-70$ & VIII & 40.47 & 388.00 & $7,000.00$ \\
& IX & 40.47 & 116.60 & $3,400.00$ \\
$1970-71$ & IV & 40.47 & 43.00 & $5,500.00$ \\
& V & 40.47 & 43.80 & $4,305.00$ \\
& VI & 40.47 & 43.00 & $4,305.00$ \\
& X & 40.47 & - & $5,021.00$ \\
& & 418.50 & $1,924.07$ & $60,232.00$ \\
\hline
\end{tabular}

that are susceptible to compaction when water from the peat is drained out or removed by evaporation. Secondly, peat soil, which is common in mangrove wetlands due to accumulation of decaying plant materials, has certain physical and chemical characteristics that lead to extreme volume changes upon drying, leading to subsidence. Nearly $80 \%$ of the mangrove soil volume is made up of water, and these soils are prone to subsidence due to compaction and dewatering as well as insufficient and irregular supply of fresh sediments ${ }^{1}$. Selvam et al. ${ }^{31}$ observed this phenomenon in the clear-felled areas in the Pichavaram and Muthupet mangroves in Tamil Nadu. As shown in Figure 1, development of hypersaline condition due to subsidence and subsequent stagnation and evaporation of tidal water prevented natural regeneration of mangrove species. Failure of mangrove regeneration in the clear-felled areas both by coppice shoots and seeds was reported in many of the Annual Administration Reports of the Forest Departments of the Madras Presidency starting from the late $1890 \mathrm{~s}$. The working plans of mangroves prepared during the post-colonial period mentioned these areas as saline blanks. Restoration of the saline blanks with mangrove species posed great chal- lenges to the colonial and post-colonial foresters. Though in the mid-1990 methods of restoring these saline blanks were developed and demonstrated by the M.S. Swaminathan Research Foundation (MSSRF, Chennai) with participation of the local community and Forest Departments of Tamil Nadu, Andhra Pradesh and Odisha ${ }^{32}$, large saline blanks created mainly by clear felling still exist in all the major mangroves of India and their restoration through joint mangrove management approach needs urgent attention.

1. Anon., Mangrove forest management guidelines, FAO Forestry Paper 117, Food and Agriculture Organization, Rome, Italy, 1994, p. 319.

2. Englefield, H. C., Dyce, W., Gregson, M., Gill, T., Howison, J. and Machlachlan, J., Papers in Chemistry. Trans. R. Soc. Encourage. Arts, Manuf Commerce, 1804, 22, 141-218.

3. Belfour, E., The Timber Trees. Timber and Fancy Woods of India and Eastern and Southern India, Higginbotham and Co, Madras, 1870 , p. 370.

4. Watt, G., A Dictionary of the Economic Products of India, Department of Revenue and Agriculture, Government of India, Calcutta, 1890, p. 337.

5. Haeuber, R., Indian forest policy in two eras: continuity or change? Environ. Hist. Rev., 1993, 17, 49-76.

6. Guha, R., Forestry in British and post-British India: a historical analysis. Econ. Polit. Wkly, 1983, 18, 1882-1896.

7. Rengarajan, M., Imperial agendas and India's forests: the early history of Indian forestry, 1800-1870. Indian Econ. Soc. Hist. Rev., 1994, 32, 147-167.

8. Stebbing, E. P., The Forests of India Vol. I, John Land the Bodley Head Limited, London, UK, 1922, p. 548.

9. Cleghorn, H., Forbes, R., Smith, B. and Strachey, R., Report of the Committee by the British Association to Consider the Probable Effects of Economical and Physical Point of View of the Destruction of Tropical Forests. British Association for the Advancement of Science, London, UK, 1852, p. 26.

10. Preseler, F., Forest management in the Sundarbans, 1875-1952. In Proceedings of the International Workshop on The Commons in South Asia: Societal Pressures and Environmental Integrity in the Sundarbans of Bangladesh, Smithsonian Institution, Washington DC, USA, 1991.

11. Guha, R., An early environmental debate: the making of the 1878 Forest Act. Indian Econ. Soc. Hist. Rev., 1990, 27, 65-84. 
12. Ribbentrop, B., Forestry in British India, Government of India Press, Calcutta, 1900, p. 245.

13. Pargiter, F. E., A Revenue History of the Sundarbans from 1765 to 1870, Bengal Secretariat Press, Calcutta, 1885, p. 318.

14. Cleghorn, H., The Forests and Gardens of South India, W. H. Allen and Co, London, UK, 1861, p. 401.

15. Hunter, W. W., Statistical Account of the Districts of the 24 Parganas and the Sundarbans, Trubner and Co, London, UK, 1875, p. 389.

16. Hossain, S. S., The Completion Report of Survey and Settlement for Kanika Estate, Bengal Secretariat Press, Calcutta, 1895, p. 165.

17. Schlich, W., Remarks on the Sunderbans. Indian For, 1876, 1 , 6-11.

18. Anon., Annual Administration Report of the Forest Department of Madras Presidency for the year 1900-01, Government Press, Madras 1901, p. 77.

19. Hemingway, F. R., Madras Districts Gazetteers: Godavari, Government Press, Madras, 1907, p. 288.

20. Qureshi, M., Botanical and silvicultural features of mangrove features. In Proceedings of the Mangrove Symposium, Ministry of Food and Agriculture (MoFA), Government of India (GoI), Calcutta, 1957.

21. Rao, V. S., Mangrove forests and the problems of reclaiming saline blanks. In Proceedings of the Mangrove Symposium, MoFA, GoI, Calcutta, 1957.

22. Curtis, S. J., Working Plan for the Forests of Sundarbans Division 1931-1951, Bengal Government Press, Calcutta, 1931, p. 175.

23. Cornwell, R. B., Working Plan for the Godavari Lower Division 1934-1944, Government Press, Madras, 1937.

24. Mathuada, G. S., The mangroves of India. In Proceedings of the Mangrove Symposium, MoFA, GoI, Calcutta, 1957.

25. Anon., Annual Administration Report of the Forest Department, Madras Presidency for the year 1894-95, Government Press, Madras, 1896, p. 340.
26. Gadgil, M. and Guha, R., This Fissured Land: An Ecological History of India, Oxford University Press, New Delhi, 2013, p. 241.

27. Karunakaran, M. S., Working Plan for the Thanjavur Forest Division 1971-1981, Forest Department, Government of Tamil Nadu, 1971, p. 347.

28. Allen, A. S., Types of land subsidence. In Guidebook to Study Land Subsidence due to Groundwater Withdrawal (ed. Polland, J. F.), UNESCO, Paris, France, 1984, pp. 133-142.

29. USDA, Soil Survey Manual, United States Department of Agriculture Handbook No.18, United States Department of Agriculture, Washington DC, USA, 1995.

30. Stephens, J. C. and Speir, W. H., Subsidence of organic soils in the USA. In Land Subsidence (ed. Tison, L. J.), International Association Science Hydrology Publication No. 89, USA, 1969, pp. 523-534.

31. Selvam, V., Ravichandaran K. K., Gnanappazham, L. and Navamunnyamal, N., Assessment of community-based restoration of Pichavaram mangrove wetland using remote sensing data. Curr. Sci., 2003, 86, 794-798.

32. MSSRF, The Mangrove Decade Beyond: Activities, Lessons and Challenges in Mangrove Conservation and Management 19912001, M.S. Swaminathan Research Foundation, Chennai, 2003, p. 40.

ACKNOWLEDGEMENTS. I thank Dr M. S. Swaminathan, MSSRF, Chennai for guidance and encouragement. I also thank Dr Madhura Swaminathan, and Dr K. S. Murali (MSSRF) for providing the necessary facilities and support.

Received 15 October 2020; accepted 9 November 2020

doi: $10.18520 / \mathrm{cs} / \mathrm{v} 120 / \mathrm{i} 5 / 766-771$ 